\title{
Expanding the Phenotypic Spectrum of GPI Anchoring Deficiency Due to Biallelic Variants in GPAA1
}

Alison M.R. Castle, MD, Smrithi Salian, PhD, Haim Bassan, MD, Efrat Sofrin-Drucker, MD, Raffaella Cusmai, MD, Kristin C. Herman, MD, Delphine Heron, MD, Boris Keren, MD, PhD, Devon L. Johnstone, MD, MSc, Wendy Mears, PhD, Susanne Morlot, MD, Thi Tuyet Mai Nguyen, PhD, Rachel Rock, MD, Elliot Stolerman, MD, Julia Russo, MS, William Boyce Burns, MD, Julie R. Jones, PhD, Valentina Serpieri, PhD,

Hannah Wallaschek, MD, Ginevra Zanni, MD, PhD, David A. Dyment, DPhil, MD, and Philippe M. Campeau, MD

Neurol Genet 2021;7:e631. doi:10.1212/NXG.0000000000000631

\section{Abstract}

\section{Background and Objectives}

To expand the clinical knowledge of GPAA1-related glycosylphosphatidylinositol (GPI) deficiency.

\section{Methods}

An international case series of 7 patients with biallelic GPAA1 variants were identified. Clinical, biochemical, and neuroimaging data were collected for comparison. Where possible, GPIanchored proteins were assessed using flow cytometry.

\section{Results}

Ten novel variants were identified in 7 patients. Flow cytometry samples of 3 available patients confirmed deficiency of several GPI-anchored proteins on leukocytes. Extensive phenotypic information was available for each patient. The majority experienced developmental delay, seizures, and hypotonia. Neuroimaging revealed cerebellar anomalies in the majority of the patients. Alkaline phosphatase was within the normal range in 5 individuals and low in 1 individual, as has been noted in other transamidase defects. We notably describe individuals either less affected or older than the ones published previously.

\section{Discussion}

Clinical features of the cases reported broaden the spectrum of the known phenotype of GPAA1-related GPI deficiency, while outlining the importance of using functional studies such as flow cytometry to aid in variant classification.

\author{
Correspondence \\ Dr. Campeau \\ p.campeau@umontreal.ca
} From the Department of Genetics (A.M.R.C., D.A.D.), Children's Hospital of Eastern Ontario, Ottawa; CHU Sainte Justine Research Centre (S.S., T.T.M.N., P.M.C.), Université de Montréal,
Quebec, Canada; Pediatric Neurology \& Development Center (H.B.), Shamir (Assaf Harofeh) Medical Center, Zerifin, Tel Aviv University; Pediatric Genetics Clinic (E.S.-D.), Schneider
Children's Medical Centre, Petach Tikya, Tel Aviv University, Israel; Unit of Neurophysiology, Department of Neurosciences, IRCCS, Bambino Gesù Research Hospital, Rome, Italy;
Section of Medical Genomics (K.C.H.), Medical Investigation of Neurodevelopmental Disorders Institute, University of California, Davis, Sacramento; APHP (B.K.), Département de
Génétique, Groupe Hospitalier Pitié Salpêtrière, Paris, France; APHP Sorbonne-Université (D.H.), UF Génétique Médicale, Hôpitaux Pitié-Salpêtrière et Trousseau, Centre de Référence
"déficiences intellectuelles de causes rares", Paris, France; Children's Hospital of Eastern Ontario Research Institute (D.L.J., W. M., D.A.D.), Ottawa, Canada; Department of Human
Genetics (S.M., H.W.), Hannover Medical School, Germany; Biochemical Diseases (R.R.), BC Children's Hospital, Vancouver, British Columbia, Canada; Greenwood Genetic Center (E.S.,
J.R., W.B.B., J.R.J.), SC; Department of Molecular Medicine (V.S.), University of Pavia; Neurogenetics Research Center (V.S.), IRCCS Mondino Foundation, Pavia; Unit of Neuromuscular
and Neurodegenerative Disorders (G.Z.), Department of Neurosciences, IRCCS, Bambino Gesù Research Hospital, Rome, Italy; and Medical Genetics Division (P.M.C.), Department of
Pediatrics, Sainte-Justine University Hospital Centre, Montreal, Quebec, Canada.
Funding information and disclosures are provided at the end of the article. Full disclosure form information provided by the authors is available with the full text of this article at 


\section{Glossary}

$\mathbf{A P}=$ anchored protein; ALP = alkaline phosphatase FLAER = fluorescein-labeled proaerolysin; $\mathbf{G P I}=$ glycosylphosphatidylinositol; WES = whole-exome sequencing.

The glycosylphosphatidylinositol (GPI) anchor pathway plays an essential role in posttranslational modification of a variety of proteins integral to cell signaling and function. ${ }^{1}$ Proteins targeted for GPI modification are captured in the cytoplasm and translocated to the endoplasmic reticulum where they acquire the GPI moiety. They are then transferred to the Golgi apparatus for remodeling and maturation of the GPI-anchored protein (GPI-AP), before being transferred to the plasma membrane. These proteins localize to numerous cell types and play integral roles in a variety of cellular processes. Examples of GPI-APs include $\mathrm{F} c \gamma$ receptors such as CD16, regulators of the complement pathway such as CD59, and cell surface enzymes such as alkaline phosphatase (ALP). ${ }^{2,3}$ In the nervous system, GPI-APs play an vital role in axon growth, axon regeneration, synapse formation, and synaptic plasticity. ${ }^{4}$ Dysfunction of neural GPI-APs has been linked to a variety of neurologic diseases including autism spectrum disorder, schizophrenia, and MS. ${ }^{4}$

Numerous neurodevelopmental disorders have been associated with variants in genes involved in the biosynthesis of GPIs. Inherited GPI deficiency disorders, also referred to as glycosylphosphatidylinositol biosynthesis defects or GPIBDs, are a group of autosomal recessive or X-linked recessive syndromic intellectual disability disorders. In 2006, the first cases of inherited GPI deficiency were documented, with the descriptions of patients with thrombosis and seizures who were found to have biallelic pathogenic variants in PIGM. ${ }^{5}$ More recently, extensive phenotypic descriptions of patients with variations in several genes (e.g., PIGN, PIGT, PIGY, and PIGK) in the pathway have been published. ${ }^{6-9}$ GPAA1 encodes a subunit of the GPI-lipid anchor transamidase complex. ${ }^{10}$ Its role in human cancers has been described since $2006^{11}$; however, its delineation as a cause of syndromic intellectual disability is more recent. ${ }^{2}$

A cohort of 10 patients from 5 families are the only reported individuals affected by GPAA1-related GPI deficiency (OMIM 617810), also known as GPI biosynthesis defect $15^{2}$ Patients with pathogenic variants in GPAAl have developmental delay, hypotonia, seizures, cerebellar atrophy, dysarthria, dysmetria, ataxia, osteopenia, and variable dysmorphic features. ${ }^{2}$ In this study, we describe and broaden the clinical and biochemical variability associated with GPAA1related GPI deficiency in an additional 7 families.

\section{Methods}

Seven individuals from unrelated families with biallelic GPAA1 variants (GenBank: NM_003801.3) are included in this case series. Individuals were identified from international centers through direct communication between clinicians and the authors of the original GPAAl case series. Whole-exome sequencing (WES) was performed on both research and clinical bases according to protocols laid out by the respective laboratories (Supplemental Data, links.lww.com/NXG/ A479). Developmental assessments were performed by pediatricians, pediatric neurologists, and developmental pediatricians. Seizure and EEG classification were performed by neurologists or pediatric neurologists. Dysmorphology examinations were performed by medical geneticists.

\section{Standard Protocol Approvals, Registrations, and Patient Consents}

Informed consent including consent for publication of photographs, imaging, and clinical information was obtained from each family in accordance with guidelines established by the institutional review boards at their primary site of care. CARE reporting guidelines were followed while preparing this article. ${ }^{12}$

\section{Fluorescence-Activated Cell Sorting Analysis}

Blood samples collected from 3 of the 7 patients (II, III, and VII), 3 different healthy controls, and the father of an affected individual were subjected to flow cytometry to assess the effect of GPAA1 variants on the cell surface GPI-APs on granulocytes. Blood samples were stained for an hour on ice with phycoerythrin-conjugated anti-human CD16 (BioLegend), fluorescein-labeled proaerolysin (FLAER)-Alexa 448 (Cedarlane), and fluorescein isothiocyanate-conjugated mouse anti-human CD55 or CD59 (BD PharMingen). Samples were treated with fluorescence-activated cell sorting Lysing Solution (BD Biosciences) before flow cytometry analysis (BD FACSCanto II system (BD Biosciences). FlowJo software (v9.5.3, Tommy Digital) was used to analyze the data.

\section{Data Availability}

Original data can be made available on request; genetic data or clinical data sharing may be subject to privacy restrictions.

\section{Results}

Clinical presentations of the 7 patients are outlined in Table 1. Patients were $43 \%$ male $(3 / 7)$. The age of the patients was variable, ranging from 6 weeks to 3 years at the time of diagnosis. Symptom onset was generally between birth and 4 months, when hypotonia was noted. All patients presented with developmental delays or intellectual disability of varying severity. Epilepsy was seen in 6/7 individuals, with the first seizure occurring between 8 months to 3 years. Numerous seizure types were observed, with 4 patients experiencing 
Table 1 Key Clinical Features of Previously Reported and New Patients

\begin{tabular}{|c|c|c|c|c|c|c|c|c|c|}
\hline & New patients & & & & & & & Total & $\begin{array}{l}\text { Nguyen } \\
\text { et al. }{ }^{2}\end{array}$ \\
\hline & 1 & II & III & IV & v & $\mathrm{VI}$ & VII & $\begin{array}{l}7 \\
\text { patients }\end{array}$ & $\begin{array}{l}10 \\
\text { patients }\end{array}$ \\
\hline Sex & M & $\mathrm{F}$ & $\mathrm{F}$ & $\mathrm{F}$ & $\mathrm{F}$ & M & M & $\begin{array}{l}3 / 7 \\
\text { male }\end{array}$ & $5 / 10$ male \\
\hline Diagnosis & $15 \mathrm{mo}$ & $10 w$ & 3 у 3 mo & $6 w$ & $8 \mathrm{mo}$ & $22 \mathrm{mo}$ & $12 \mathrm{mo}$ & - & - \\
\hline $\begin{array}{l}\text { Last } \\
\text { assessment }\end{array}$ & $38 \mathrm{y}$ & $22 \mathrm{mo}$ & 3 y 9 mo & 5 y 3 mo & 3 y 9 mo & $\begin{array}{l}5 \text { y } 5 \\
\text { mo }\end{array}$ & $3 y$ & - & 4-30 yo \\
\hline Height (cm) & $170(17 \%)$ & $\begin{array}{l}75 \\
(<1 \%)\end{array}$ & $88(<1 \%)$ & $111(33 \%)$ & $90(1 \%)$ & $\begin{array}{l}105 \\
(7 \%)\end{array}$ & $\begin{array}{l}97 \\
(59 \%)\end{array}$ & - & $-(<1-59 \%)$ \\
\hline Weight (kg) & 78 (72\%) & $\begin{array}{l}10.1 \\
(23 \%)\end{array}$ & $12.1(3 \%)$ & $26(96 \%)$ & $11(<1 \%)$ & $\begin{array}{l}17.7 \\
(31 \%)\end{array}$ & $\begin{array}{l}15.3 \\
(72 \%)\end{array}$ & - & $-(16-58 \%)$ \\
\hline OFC $(\mathrm{cm})$ & $59.5(93 \%)$ & $\begin{array}{l}45.3 \\
(13 \%)\end{array}$ & $46(1 \%)$ & $45(<1 \%)$ & $46(2 \%)$ & $\begin{array}{l}51.5 \\
(69 \%)\end{array}$ & $\begin{array}{l}49 \\
(34 \%)\end{array}$ & - & $-(<1-87 \%)$ \\
\hline DD/ID & ++ & + & +++ & +++ & +++ & Present & +++ & $\begin{array}{l}100 \% \\
(7 / 7)\end{array}$ & $\begin{array}{l}100 \% \\
(10 / 10)\end{array}$ \\
\hline Hypotonia & Yes & No & Yes & Yes & Yes & Yes & Yes & $\begin{array}{l}86 \% \\
(6 / 7)\end{array}$ & $\begin{array}{l}100 \% \\
(10 / 10)\end{array}$ \\
\hline Seizures & $\begin{array}{l}\text { Febrile, } \\
\text { absence, and } \\
\text { BTC }\end{array}$ & No & $\begin{array}{l}\text { Febrile, epileptic } \\
\text { spasms, and } \\
\text { myoclonic jerks }\end{array}$ & Febrile & $\begin{array}{l}\text { Febrile, startle, } \\
\text { myoclonic, absence, } \\
\text { BTC, and status } \\
\text { epilepticus }\end{array}$ & Yes & BTC & $\begin{array}{l}86 \% \\
(6 / 7)\end{array}$ & $\begin{array}{l}70 \% \\
(7 / 10)\end{array}$ \\
\hline $\begin{array}{l}\text { Cerebellar } \\
\text { atrophy }\end{array}$ & Yes & No & Yes & No & Yes & NA & No & $\begin{array}{l}50 \% \\
(3 / 6)\end{array}$ & $\begin{array}{l}90 \% \\
(9 / 10)\end{array}$ \\
\hline $\begin{array}{l}\text { Neurologic } \\
\text { features }\end{array}$ & $\begin{array}{l}\text { At, DA, and } \\
\text { DM }\end{array}$ & None & Sp & At and Ny & Ny and Sp & None & At & - & - \\
\hline Osteopenia & Yes $(Z=-2.3)$ & NA & NA & NA & NA & NA & No & $\begin{array}{l}50 \% \\
(1 / 2)\end{array}$ & $\begin{array}{l}100 \% \\
(8 / 8)\end{array}$ \\
\hline $\begin{array}{l}\text { Dysmorphic } \\
\text { features }\end{array}$ & $\begin{array}{l}\text { Prominent } \\
\text { forehead, } \\
\text { hypertelorism }\end{array}$ & No & $\begin{array}{l}\text { Prominent forehead, } \\
\text { deep set eyes, down- } \\
\text { slanting PFs, small } \\
\text { chin, and tented } \\
\text { upper lip }\end{array}$ & $\begin{array}{l}\text { Broad forehead, } \\
\text { upslanting PFs, } \\
\text { epicanthus, arched } \\
\text { narrow palate, tented } \\
\text { upper lip, and protruding } \\
\text { ear lobes }\end{array}$ & $\begin{array}{l}\text { Epicanthal folds, } \\
\text { upslanting palpebral } \\
\text { fissures, tented } \\
\text { upper lip, and flat } \\
\text { nasolabial folds }\end{array}$ & $\begin{array}{l}\text { Single } \\
\text { palmar } \\
\text { crease }\end{array}$ & No & $\begin{array}{l}57 \% \\
(4 / 7)\end{array}$ & $\begin{array}{l}80 \% \\
(8 / 10)\end{array}$ \\
\hline Plasma ALP & Normal & Normal & Low & Normal & Normal & NA & Normal & $\begin{array}{l}83 \% \\
(5 / 6)\end{array}$ & $\begin{array}{l}100 \% \\
(10 / 10)\end{array}$ \\
\hline
\end{tabular}

Abbreviations: + = mild; ++ = moderate; +++ = severe; $\mathrm{At}=$ ataxia; $\mathrm{BTC}=$ bilateral tonic-clonic; $\mathrm{DA}=$ dysarthria; $\mathrm{DD}=$ developmental delay; $\mathrm{DM}=\mathrm{dysmetria;} \mathrm{ID}=$ intellectual disability; $\mathrm{Ny}$ = nystagmus; $\mathrm{OFC}=$ occipitofrontal circumference; $\mathrm{PF}=$ palpebral fissures; $\mathrm{Sp}=$ spasticity.

febrile seizures, 2 patients with absence seizures, 3 patients with bilateral tonic-clonic seizures, 2 patients with myoclonic jerks, and 1 patient experiencing epileptic spasms. Only 1 patient, aged 22 months, had not experienced a seizure. EEG data were available for 5 patients and showed variable findings, including normal, nonspecific changes, spike/polyspike discharges, multifocal spike and wave, and slow wave epileptiform discharges; no common EEG pattern was seen. Patients were maintained on a variety of antiepileptic medications (Supplemental Data, links.lww.com/NXG/A479).

Six of 7 patients were described as hypotonic and 2 demonstrated spasticity. In all patients with hypotonia, it was either present at birth or noted before 4 months of age. Cerebellar atrophy was seen in $3 / 6$ patients (Figure 1 and eFigure 2, links. lww.com/NXG/A479). It was progressive in 1 patient (eFigure 1), with imaging at 7 months of age demonstrating benign enlargement of the subarachnoid space of infancy with a normal cerebellum. Imaging was repeated at age 2 years and demonstrated mild diffuse and symmetrical brain atrophy with progression in the cerebellum. The second patient did not have neuroimaging until age 21 years; this demonstrated cerebellar atrophy, which has been stable on repeat imaging at ages 25 and 29 years. The third patient with cerebellar atrophy has not been assessed with serial MRIs. In 2 of these individuals, additional abnormalities were noted, including slightly delayed myelination and mild thinning or hypoplasia of the corpus callosum. 

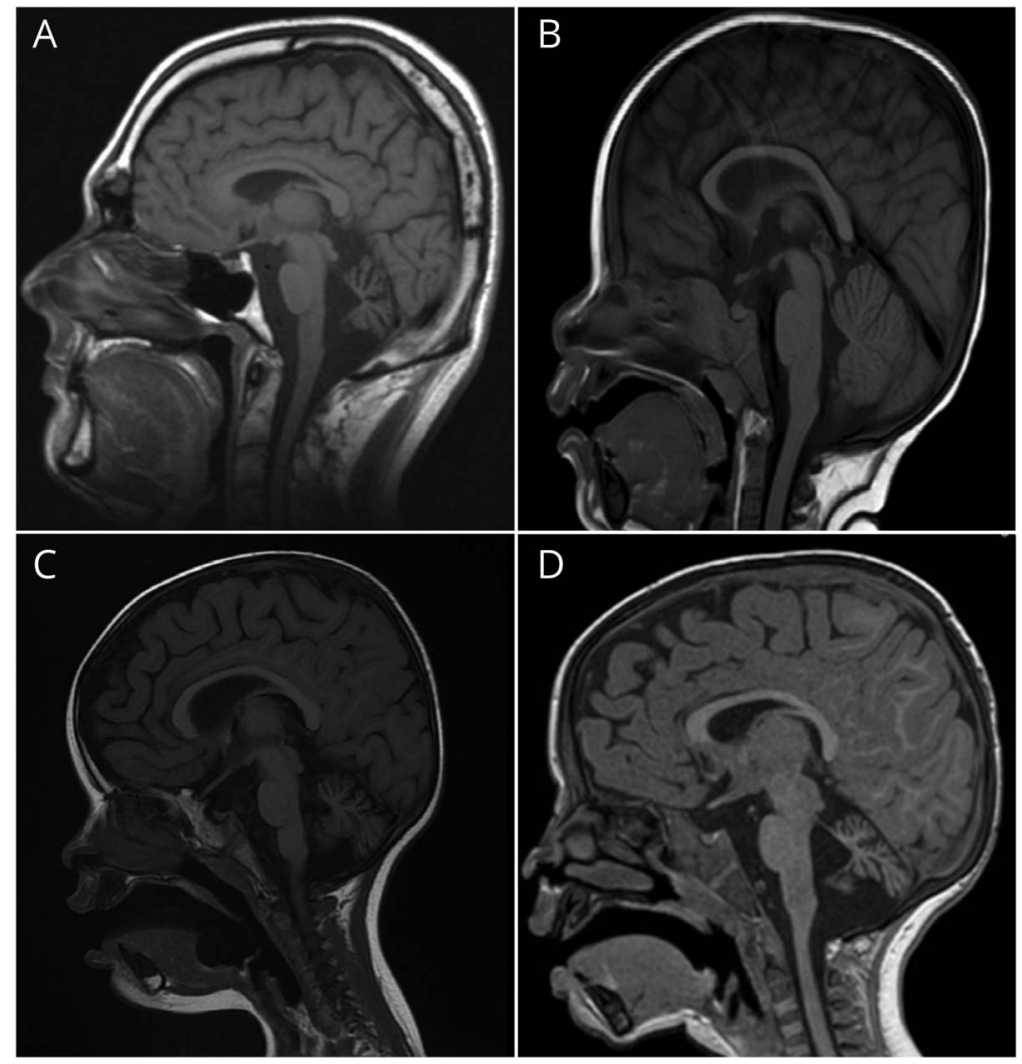

(A) Neuroimaging from patient I, taken at age 21 years. Note the cerebellar atrophy with prominent folia. (B) Sagittal T1 MRIs from patient II, in whom biallelic GPAA1 variants were found incidentally on exome sequencing. The cerebellum is normal in this patient. (C) Neuroimaging from patient III from 2018. Although her initial MRI did not report cerebellar hypoplasia/atrophy, subsequent cerebellar atrophy was noted on this follow-up imaging (shown) performed at age 2 years. Slightly delayed myelination and mild thinning of the corpus callosum was also identified. (D) Sagittal T1 MRI images from patient $\mathrm{V}$, showing severe vermian hypoplasia/ atrophy and thinning of the superior cerebellar peduncle and bilateral cerebellar hemisphere atrophy. The corpus callosum was also noted to be hypoplastic.

Associated features included nystagmus in 2 patients, dysarthria in 1 patient (not assessed in 4 patients given their age or language capacity), dysmetria in 1 patient, and ataxia in 3 patients. Osteopenia was present in 1 patient with a bone density $\mathrm{Z}$ score of -2.3 ; however, it was not assessed in 5 patients in the cohort. Plasma ALP levels were within the normal range in 5 patients and low in 1 patient. Variable dysmorphic features were described, with common descriptions including prominent forehead and a tented upper lip. Three patients were not dysmorphic.

We identified novel variants in GPAA1 in all cases (Table 2, Figure 2). Variants were identified on clinical WES in 5 patients and research WES in the remaining 2 patients. Indications for testing included developmental delay, hypotonia, seizures, and ataxia (Supplemental Data, links.lww.com/NXG/A479). In total, there were 10 new variants identified in the 7 patients, as 3 patients were homozygous for GPAA1 variants, and 2 unrelated patients were observed to carry the same variant. Seven variants were missense: c.164T>C (p.Met55Thr), c.1049T>G (p.Leu350Arg), c.917A >G (p.His306Arg), c.1559T>G (p.Leu520Arg), c.947C > T (p.Ala316Val), c.1831T>C (p.Trp611Arg), and c.149T >A (p.Met50Lys). Three variants were deletions resulting in frameshifts: c.1233_1239del (p.Pro412Tyrfs*19), c.1477_1478del (p.Arg493Glyfs* 152), and c.619delA (p.Met207Cysfs ${ }^{*} 21$ ). No nonsense variants were identified in this cohort of patients (eTable 1).
FLAER staining is used as a marker of total GPI-APs, ${ }^{2,13}$ and specific GPI-APs such as CD16 can be quantified via flow cytometry. To assess the effect of the GPAA1 variants on the biosynthesis of GPI-APs, flow cytometry analyses were performed on blood samples from 3 patients. On the granulocytes of patients II, III, and VII, there was a 47\%, 37\%, and $12 \%$ decrease in the CD16 level compared with healthy controls, respectively (Figure 3). CD55, CD59, and total GPIAP levels in these individuals showed slightly decreased or no change in the levels compared with healthy controls. The father of an affected parent, who carries a frameshift variant in GPAA1, did not have abnormalities on flow cytometry (eFigure 3, links.lww.com/NXG/A479).

\section{Discussion}

The present report of 7 new cases of GPAA1-related GPI deficiency both affirms and expands on the phenotype previously described. ${ }^{2}$ The most common features seen in the series are seizures, developmental delay, and hypotonia.

Variability in this cohort was marked. Patient II had a considerably milder clinical phenotype compared with the other patients in both this and the previously reported cohort. At age 22 months, the patient had developmental delay, most notably in motor milestone acquisition and adaptive development. Her problem solving, receptive language, and 
Table 2 Genetic Description of GPAA1 Variants

\begin{tabular}{|c|c|c|c|c|c|c|}
\hline Patient & Genomic variant $^{a}$ & cDNA variant $^{\mathrm{b}}$ & Protein variant & Zygosity & Inheritance & $\begin{array}{l}\text { Pathogenicity } \\
\text { score (CADD) }\end{array}$ \\
\hline $\mathbf{I}$ & chr8: g.145138116T>C & C. $164 T>C$ & p.Met55Thr & Homozygous & Maternal + paternal & 24 \\
\hline II & chr8: g.145139663T>G & c. $1049 \mathrm{~T}>\mathrm{G}$ & p.Leu350Arg & Homozygous & Maternal + paternal & 27 \\
\hline \multirow[t]{2}{*}{ III } & chr8: g.145139419A>G & c. $917 A>G$ & p.His306Arg & Compound heterozygous & Maternal & 23.3 \\
\hline & chr8: g.145140583T>G & c.1559T>G & p.Leu520Arg & Compound heterozygous & Paternal & 27.3 \\
\hline IV & chr8: g.145139449C>T & c.947C $>\mathrm{T}$ & p.Ala316Val & Homozygous & Maternal + paternal & 28.3 \\
\hline \multirow[t]{2}{*}{ v } & chr8: g.145139449C>T & c.947C $>\mathrm{T}$ & p.Ala316Val & Compound heterozygous & Paternal & 28.3 \\
\hline & chr8:g.145140014-145140020del & $\begin{array}{l}\text { c.1233 } \\
\text { 1239del }\end{array}$ & p.Pro412Tyrfs*19 & Compound heterozygous & Maternal & \\
\hline \multirow[t]{2}{*}{ VI } & chr8:g.145140501-145140502del & $\begin{array}{l}\text { c.1477- } \\
1478 \text { del }\end{array}$ & p.Arg493Glyfs*152 & Compound heterozygous & Maternal & \\
\hline & chr8: g.145140993T>C & c. $1831 \mathrm{~T}>\mathrm{C}$ & p.Trp611Arg & Compound heterozygous & Paternal & 32 \\
\hline \multirow[t]{2}{*}{ VII } & chr8: g.145139039del & c.619delA & p.Met207Cysfs*21 & Compound heterozygous & Paternal & \\
\hline & chr8: g.145138101T>A & c. $149 \mathrm{~T}>\mathrm{A}$ & p.Met50Lys & Compound heterozygous & Maternal & 24.6 \\
\hline
\end{tabular}

socioemotional function was slightly below expected for her age. She has no seizures, hypotonia, or cerebellar atrophy (Figure 1). In all other individuals, hypotonia presented within the first 4 months of life. Seizures are more variable in onset; however, most patients in this case series had onset of epilepsy before 22 months (Supplemental Data, links.lww. com/NXG/A479). Her main medical concern was early onset inflammatory bowel disease; GPAAl variants were considered incidental findings on exome sequencing. However, flow cytometry assays support the pathogenicity of the variants by demonstrating reduction in CD16 in granulocytes. Similar to other patients in this series, there was no decrease in other markers. Taken together, her clinical and biochemical findings could suggest a milder variant, and she will continue to be monitored for disease manifestations.

Patient $\mathrm{I}$ is, to date, the oldest individual reported with GPAA1 deficiency. His clinical presentation includes many cardinal features of the disorder, including neonatal hypotonia, generalized epilepsy with multiple seizure types, stable global cerebellar atrophy (eFigure 2, links.lww.com/NXG/ A479), osteopenia, and normal ALP. He exhibits several cerebellar symptoms including ataxia, dysarthria, and dysmetria. He has impairments in fine motor skills and is unable to stand, read, or write, however he does eat and undress independently.

Clinical features reported in these patients reflect what was described in the first cohort of patients with GPAA1-related GPI deficiency. ${ }^{2}$ Developmental delay of variable severity was universal in both cohorts. Two patients are nonverbal; all others had delayed language acquisition and ongoing impaired communication. All patients had delayed motor development: 1 patient cannot sit independently; others achieved this milestone between 11 months and 4 years. Ambulation is present in 1 patient, achieved at 6 years; however, the majority of patients in the cohort remain below age 6 years and may ambulate in the future (Supplemental Data, links.lww.com/NXG/A479). Hypotonia and seizures were also seen in comparable frequencies (Table 1). No common seizure type or EEG pattern was identified. Cerebellar atrophy was seen less frequently, with only $50 \%$ of patients demonstrating this finding on neuroimaging. Other intracranial abnormalities are seen in some individuals, including delayed myelination, mild thinning of the corpus callosum, and hypoplasia of the corpus callosum. Similar anomalies have been described in patients with other GPIBDs, reflective of the importance of GPI-APs in neural development. ${ }^{4,14-16}$ Flow cytometry identified decreased levels of only CD16 compared with previously reported patients with decreased CD16, CD59, and total GPI-AP. ${ }^{2}$ A characteristic flow cytometry profile in granulocytes has been described for individuals with PIGU and PIGT variants. ${ }^{16}$ GPAA1 deficiency does not demonstrate a characteristic pattern; however, measuring GPI-APs through flow cytometry remains a mechanism by which functional consequences of GPAA1 variants can be investigated.

Similar to the previous cohort, no homozygous loss-of-function variants were identified in this series of patients. This is suggestive of the importance of having residual functional gene product, a hypothesis supported by the fact that this pathway is 


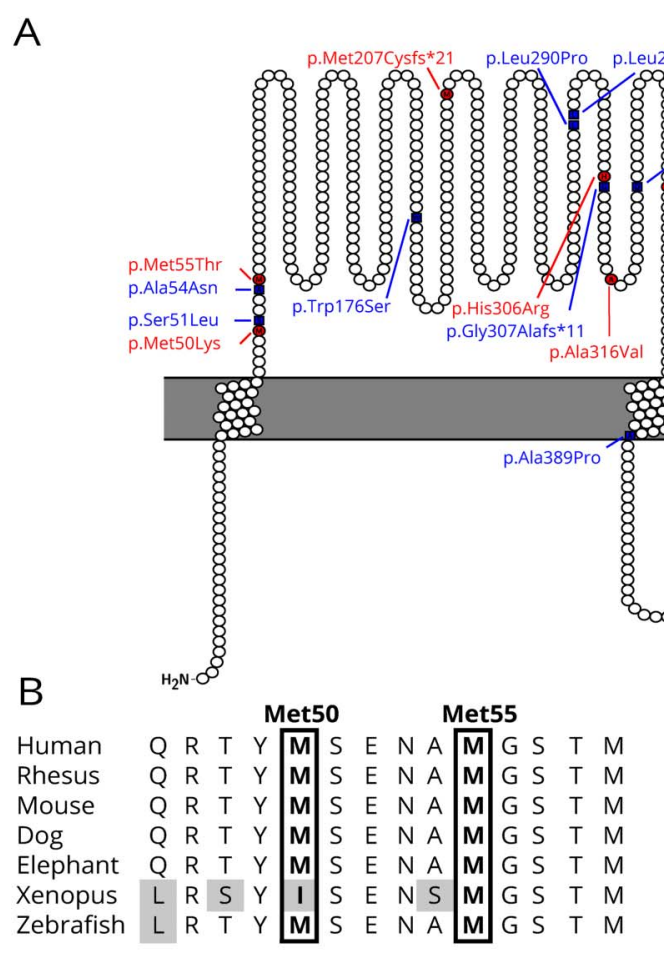

\begin{tabular}{|c|c|c|c|c|c|c|c|}
\hline & \multicolumn{7}{|c|}{ Ala316 } \\
\hline Human & $Y$ & $R \vee$ & $E$ & $\bar{A}$ & L T & L & $\mathrm{R}$ \\
\hline Rhesus & $Y$ & $\mathrm{R} V$ & $E$ & A & L T & $\mathrm{L}$ & 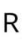 \\
\hline Mouse & $Y$ & $\mathrm{G} \vee$ & $E$ & A & $\mathrm{L} \quad \mathrm{T}$ & $\mathrm{L}$ & R \\
\hline Dog & $Y$ & $R \vee$ & $E$ & A & L T & 1 & \\
\hline Elephant & Y & $\mathrm{R} V$ & $E$ & A & L T & $\mathrm{L}$ & R \\
\hline Xenopus & $Y$ & $\mathrm{H} \mathrm{I}$ & $E$ & A & I T & $\mathrm{L}$ & \\
\hline Zebrafish & Y & H I & $E$ & A & A S & 1 & \\
\hline
\end{tabular}

\begin{tabular}{lllll|l|lll} 
& \multicolumn{1}{c}{ Arg493 } \\
Human & A & P & D & - & R & G & W & M \\
Rhesus & A & P & D & - & R & G & W & M \\
Mouse & V & P & D & - & R & G & W & M \\
Dog & A & P & D & - & R & G & W & M \\
Elephant & A & P & D & - & R & G & W & M \\
Xenopus & G & R & T & A & G & G & W & M \\
Zebrafish & G & T & E & - & Q & G & W & K
\end{tabular}

C

\begin{tabular}{lllll|l|llll} 
Human & C & A & G & G & M & Q & S & S & P \\
Rhesus & C & A & G & G & M & Q & S & S & P \\
Mouse & C & A & G & G & I & Q & S & S & P \\
Dog & C & A & G & G & M & Q & S & S & P \\
Elephant & C & A & G & G & M & Q & S & A & P \\
Xenopus & C & A & G & E & I & K & S & S & V \\
Zebrafish & C & A & G & G & M & E & Y & S & P
\end{tabular}

\section{Leu350}

Human L N H L L E R L H Rhesus $L N H L L E R L H$ Mouse L N H L L E R L H Dog L N H L L E R L H Elephant L N H L L E R L H Xenopus L N N L S E R L H Zebrafish L N N L L E R L H

\begin{tabular}{|c|c|c|c|c|c|c|c|c|}
\hline & \multicolumn{8}{|c|}{ Leu520 } \\
\hline tuman & T & $\mathrm{N}$ & F & $\mathrm{S}] \mathrm{L}$ & L & $G \quad F$ & L & \\
\hline hesus & $T$ & $\mathrm{~N}$ & $F$ & $\mathrm{~S} \mid \mathrm{L}$ & L & $G \quad F$ & 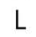 & \\
\hline Mous & L & $\mathrm{N}$ & $\mathrm{F}$ & $S \mid L$ & L & $G F$ & $\mathrm{~L}$ & \\
\hline Dog & $\mathrm{T}$ & $\mathrm{N}$ & $\mathrm{F}$ & $\mathrm{S} \mid \mathrm{L}$ & L & $G \quad F$ & L & \\
\hline Elephant & 1 & $\mathrm{~N}$ & $\mathrm{~F}$ & $\mathrm{~S} / \mathrm{L}$ & L & $G \quad F$ & $\mathrm{~L}$ & \\
\hline Xenopus & 1 & $\mathrm{~N}$ & $\mathrm{~F}$ & $\mathrm{~S} \mid \mathrm{L}$ & L & $G \quad F$ & $\mathrm{~L}$ & \\
\hline ebra & 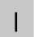 & $\mathrm{N}$ & $\mathrm{F}$ & $S$ & L & $G F$ & 1 & \\
\hline
\end{tabular}

Previously reported variants

New variants

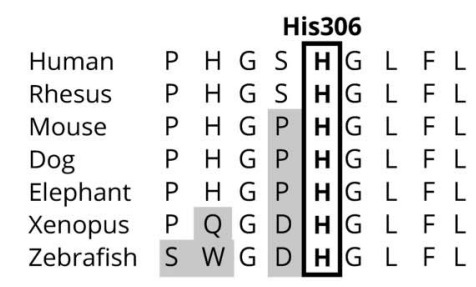

\section{Pro412}

Human G A P G P S V P L Rhesus $G$ A $P$ G $P$ P $S \vee P$ P

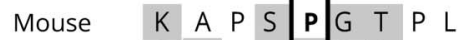
Dog G G P E Elephant G T $P$ P Xenopus - $-\cdot-\cdot-\cdot-\cdot-\cdot$ Zebrafish - - - - - - - - -

\begin{tabular}{|c|c|c|c|c|c|c|c|}
\hline & \multicolumn{7}{|c|}{ Trp611 } \\
\hline Human & L & Y & $P C$ & W & $\mathrm{L}$ & L & $\mathrm{FW}$ \\
\hline Rhesus & $\mathrm{L}$ & Y & $P C$ & W & L & L & F W \\
\hline Mouse & L & Y & $P C$ & w & L & L & F W \\
\hline Dog & L & Y & $P C$ & W & L & - & $\mathrm{F} \mathrm{W}$ \\
\hline Elephant & $\mathrm{F}$ & Y & $P C$ & W & L & L & F W \\
\hline enopus & V & Y & $P C$ & $v_{v}$ & L & & L W \\
\hline brafish & V & Y & $\mathrm{PC}$ & $\underline{W}$ & $\mathrm{~L}$ & & V \\
\hline
\end{tabular}

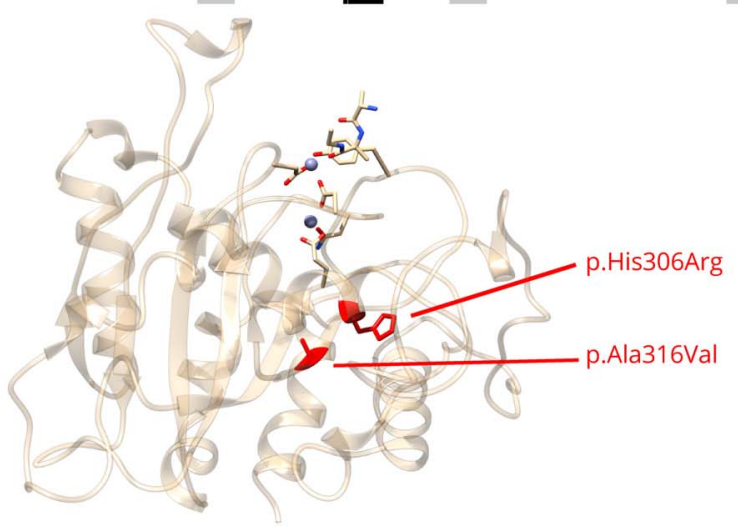

(A) Schematic representation of missense and frameshift GPAA1 variants, with previously reported variants indicated in blue, and novel variants indicated in red. (B) Amino acid conservation in vertebrates. (C) Three-dimensional modeling of the luminal domain of GPAA1, which spans residues 66-348. ${ }^{35}$ Shown in red are 2 missense variants within this domain. 

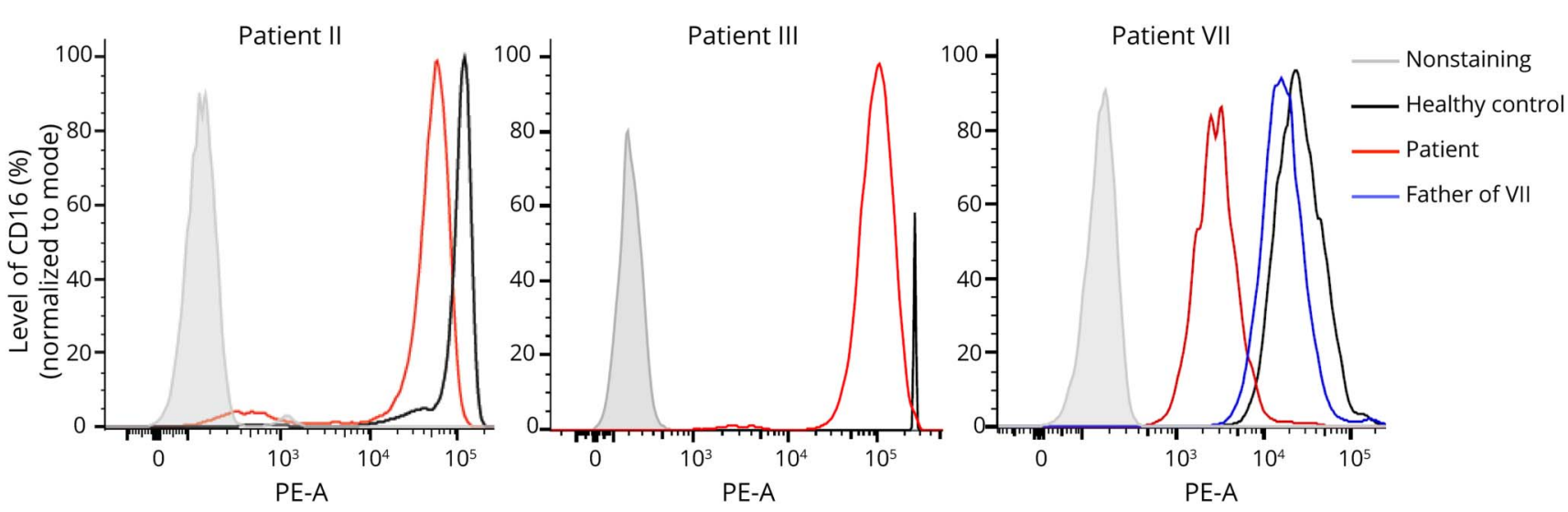

The histograms are representatives of at least 2 separate experiments using 3 different controls. There was a 47\%, 37\%, and $12 \%$ decrease in the CD 16 level on the granulocytes of patients II, III, and VII, respectively, compared with controls. In addition, there was no significant reduction in glycosylphosphatidylinositol-anchored protein levels in the father of patient VII, who carries a frameshift variant. PE-A = phycoerythrin area.

conserved in all eukaryotes. ${ }^{17}$ All variants were novel; however, a recurrent variant was identified in 2 unrelated individuals. The p.Ala316Val substitution was found in an individual of Kurdish Turk descent in a homozygous state and in an unrelated Israeli individual with compound heterozygous variants. Both patients have severe global developmental delay; however, physical anomalies vary between the 2 , including the presence of cerebellar atrophy in only the patient with compound heterozygous variants. That patient also has a more severe epileptic disorder, with poor seizure control despite multiple medications (Supplemental Data, links.lww.com/NXG/A479).

Osteopenia was a universal finding in the first cohort of patients identified by Nguyen et al. in 2017. Only 2 patients in this series have been assessed with dual-energy X-ray absorptiometry scans, with osteopenia present in 1. With ongoing surveillance of individuals with GPI-related disorders and osteopenia, it will hopefully be determined if its presence leads to adverse health outcomes. Given the independent association of osteopenia and osteoporosis with epilepsy, antiepileptic use, and decreased mobility, one may anticipate patients with GPAA1 deficiency are at risk of fractures, and bone health should be promoted and monitored. ${ }^{18}$ At least 1 individual with PIGT-related GPI deficiency has had fractures due to decreased bone mineral density. ${ }^{19}$

Osteopenia and osteoporosis are hypothesized to be secondary to decreased alkaline phosphatase (ALP) expression on the surface of osteoblasts, impairing their function and leading to decreased bone formation and therefore bone mineral density. Hyperphosphatasia is a consequence of deficient ALP membrane attachment. ALP tends to be elevated when proteins in later steps of the GPI pathway are dysfunctional, as the GPI anchor cannot be appropriately attached to the protein. The cell is left with soluble ALP that is then released into the serum. ${ }^{3}$ The GPI-transamidase complex, which includes proteins encoded by GPAA1, PIGK, PIGS, PIGT, and PIGU, mediates the attachment of the GPI anchor to targeted proteins. ${ }^{20}$ None of the patients described in the literature with pathogenic variants in GPItransamidase complex genes have elevated ALP. ${ }^{2,14,21,22}$ In fact, several patients with PIGT and PIGK pathogenic variants have decreased alkaline phosphatase. ${ }^{7,9}$ Our cohort of patients is consistent with this pattern, as none had elevated ALP or hyperphosphatasia, but 1 patient had a decreased ALP.

About half of patients with GPI-related disorders have abnormalities on neuroimaging including hypoplasia of the corpus callosum and white matter loss. ${ }^{14}$ Cerebellar hypoplasia and atrophy is noted in 10 different disorders (PIGA, PIGL, PIGN, PIGO, PIGG, PIGK, PIGS, PIGT, GPAA1, and PGAP1). ${ }^{2,6,9,14,23-28}$ In the original cohort of patients with GPAA1 deficiency, 9 of 10 patients had cerebellar anomalies; the 1 patient without cerebellar atrophy was only 1 year of age and perhaps too young to have developed the finding. Acquired cerebellar atrophy was noted in patient III of this cohort. Neuroimaging at 7 months showed a normal cerebellum; however, a repeat MRI at 2 years confirmed diffuse brain atrophy with the most striking progression in the cerebellum (see eFigure 1, links.lww.com/NXG/A479). Acquired, rather than congenital, cerebellar abnormalities may prove to be a common feature of the disorder, not yet fully appreciated as most children have MRI scans after onset of clinical manifestations caused by the presence of cerebellar atrophy. However, symptoms of nystagmus, dysarthria, and dysmetria were not congruent with the presence of cerebellar anomalies, suggesting that neuroimaging should be considered even in the absence of these signs and symptoms.

No patients had vascular anomalies including venous or capillary malformations. It was recently suggested that heterozygous loss-of-function variants in GPAA1 are associated with these anomalies. ${ }^{29}$ Data from patient cohorts published to date suggest GPAA1-related disorders are inherited in a recessive manner, and parents who carry loss-of-function variants in GPAA1 have not been found to have any health effects including vascular anomalies. As more patients are 
identified with biallelic GPAA1 variants, family studies to assess the dermatologic and vascular phenotypes in heterozygotes may provide clarity regarding this relationship. Of interest, that same publication showed that GPAA1 knock-out models of zebrafish embryos develop numerous differences, including shortened length, back hyperextension, and smaller eyes, suggesting that GPAA1 plays a critical role in embryonic development. More studies will be needed to extrapolate the relevance of these findings to affected patients.

At present, treatments for GPI-related disorders are limited and primarily focused on seizure control. There is a case report of an individual with GPI deficiency due to variants in PIGM whose severe seizures were treated successfully with the histone deacetylase inhibitor sodium butyrate. ${ }^{30,31}$ However, this is likely not a feasible treatment for all GPI-related disorders, as the patient's specific pathogenic variant was in the PIGM promotor and led to decreased acetylation and therefore decreased gene expression. Two brothers with early infantile epileptic encephalopathy due to PIGA pathogenic variants had resolution of their seizures after initiation of the ketogenic diet, but the mechanism for this has not been fully elucidated. ${ }^{32}$ Two patients in this cohort are currently or were previously managed on the ketogenic diet. In at least one of the patients, a partial but significant reduction in seizure frequency was observed. Previous case reports have discussed the efficacy of pyridoxine (B6) in seizure management in hyperphosphatasia with intellectual disability syndromes (caused by variants in PIGV, PIGY, PIGO, PGAP2, PIGW, and PGAP3). ${ }^{21,33,34}$ ALP allows pyridoxal phosphate to cross the blood-brain barrier; thus, deficiency on cellular surfaces due to impaired GPI protein anchoring may lead to cerebral B6 deficiency, which can be addressed with B6 supplementation. Three of 7 patients in this report are using B6 as a part of their treatment regimen for seizure control. In 2 of these patients, control is suboptimal with ongoing breakthrough seizures; the third patient has well-controlled epilepsy. B6 is not felt to have contributed significantly to seizure control.

This cohort of patients supports and expands on the previously described phenotype, as it includes individuals who are either older or more mildly affected than those previously described. This will allow clinicians to begin to appreciate what long-term outcomes may look like for their affected patients. Functional assays such as flow cytometry aid in identifying true pathogenic variants causing decreased GPIanchored protein expression vs variants of no functional significance, helping establish a library of causative variants. The quantitative nature of these assays in conjunction with access to clear clinical information may assist scientists in establishing a clear genotype-phenotype correlation. As is often the case in the era of next-generation sequencing, the full spectrum of GPAA1-related disorders will continue to evolve as additional patients are identified and characterized.

\section{Acknowledgment}

The authors thank the patients and families. They also thank the various research consortiums, including the Care4Rare
Research Consortium, that aided in the identification of variants in patients. G. Zanni is a member of the European Reference Network for Rare Neurological Diseases, Project ID no 739510. The authors thank Enza Maria Valente (Rome, Italy) for her assistance in molecular analysis.

\section{Study Funding}

No targeted funding reported.

\section{Disclosure}

The authors report no disclosures relevant to the manuscript. Full disclosure form information provided by the authors is available with the full text of this article at Neurology.org/NG.

\section{Publication History}

Received by Neurology: Genetics March 28, 2021. Accepted in final form August 9, 2021.

Appendix Authors

\begin{tabular}{lll}
\hline Name & Location & Contribution \\
\hline $\begin{array}{l}\text { Alison M.R. } \\
\text { Castle, MD }\end{array}$ & $\begin{array}{l}\text { Department of Genetics, } \\
\text { Children's Hospital of Eastern } \\
\text { Ontario, Ottawa, Ontario } \\
\text { Canada }\end{array}$ & $\begin{array}{l}\text { Drafting/revision of the } \\
\text { manuscript for content, } \\
\text { including medical writing for } \\
\text { content, and major role in } \\
\text { the acquisition of data }\end{array}$ \\
\hline $\begin{array}{l}\text { Smrithi } \\
\text { Salian, PhD }\end{array}$ & $\begin{array}{l}\text { CHU Sainte Justine Research } \\
\text { Centre, Universite de } \\
\text { Montreal, Montreal, Quebec, } \\
\text { Canada }\end{array}$ & $\begin{array}{l}\text { Drafting/revision of the } \\
\text { manuscript for content, } \\
\text { including medical writing for } \\
\text { content, and analysis or } \\
\text { interpretation of data }\end{array}$ \\
\hline $\begin{array}{l}\text { Haim } \\
\text { Bassan, MD }\end{array}$ & $\begin{array}{l}\text { Pediatric Neurology \& } \\
\text { Development Center, Shamir } \\
\text { (Assaf Harofeh) Medical } \\
\text { Center, Zerifin, Tel Aviv } \\
\text { University, Israel }\end{array}$ & $\begin{array}{l}\text { Major role in the acquisition } \\
\text { of data }\end{array}$ \\
\hline
\end{tabular}

\begin{tabular}{|c|c|c|}
\hline $\begin{array}{l}\text { Efrat Sofrin- } \\
\text { Drucker, MD }\end{array}$ & $\begin{array}{l}\text { Pediatric Genetics Clinic, } \\
\text { Schneider Children's Medical } \\
\text { Centre, Petach Tikya, Tel Aviv } \\
\text { University, Israel }\end{array}$ & $\begin{array}{l}\text { Major role in the acquisition } \\
\text { of data }\end{array}$ \\
\hline $\begin{array}{l}\text { Raffaella } \\
\text { Cusmai, MD }\end{array}$ & $\begin{array}{l}\text { Unit of Neurophysiology, } \\
\text { Department of } \\
\text { Neurosciences, IRCCS, } \\
\text { Bambino Gesù Research } \\
\text { Hospital, Rome, Italy }\end{array}$ & $\begin{array}{l}\text { Major role in the acquisition } \\
\text { of data }\end{array}$ \\
\hline $\begin{array}{l}\text { Kristin C. } \\
\text { Herman, MD }\end{array}$ & $\begin{array}{l}\text { Section of Medical Genomics, } \\
\text { Medical Investigation of } \\
\text { Neurodevelopmental } \\
\text { Disorders Institute, } \\
\text { University of California, } \\
\text { Davis, Sacramento, CA, USA }\end{array}$ & $\begin{array}{l}\text { Major role in the acquisition } \\
\text { of data }\end{array}$ \\
\hline $\begin{array}{l}\text { Delphine } \\
\text { Heron, MD }\end{array}$ & $\begin{array}{l}\text { APHP Sorbonne-Université, } \\
\text { UF Génétique Médicale, } \\
\text { Hôpitaux Pitié-Salpêtrière et } \\
\text { Trousseau, Centre de } \\
\text { Référence "déficiences } \\
\text { intellectuelles de causes } \\
\text { rares", Paris, France }\end{array}$ & $\begin{array}{l}\text { Major role in the acquisition } \\
\text { of data }\end{array}$ \\
\hline $\begin{array}{l}\text { Boris Keren, } \\
\text { MD PhD }\end{array}$ & $\begin{array}{l}\text { APHP, Département de } \\
\text { Génétique, Groupe } \\
\text { Hospitalier Pitié Salpêtrière, } \\
\text { Paris, France }\end{array}$ & $\begin{array}{l}\text { Major role in the acquisition } \\
\text { of data }\end{array}$ \\
\hline
\end{tabular}


Appendix (continued)

\begin{tabular}{lll}
\hline Name & Location & Contribution \\
\hline $\begin{array}{l}\text { Devon L. } \\
\text { Johnstone, } \\
\text { MD, MSc }\end{array}$ & $\begin{array}{l}\text { Children's Hospital of Eastern } \\
\text { Ontario Research Institute, } \\
\text { Ottawa, Ontario, Canada }\end{array}$ & $\begin{array}{l}\text { Drafting/revision of the } \\
\text { manuscript for content, } \\
\text { including medical writing for } \\
\text { content }\end{array}$ \\
\hline $\begin{array}{l}\text { Wendy } \\
\text { Mears, PhD }\end{array}$ & $\begin{array}{l}\text { Children's Hospital of Eastern } \\
\text { Ontario Research Institute, } \\
\text { Ottawa, Ontario, Canada }\end{array}$ & $\begin{array}{l}\text { Drafting/revision of the } \\
\text { manuscript for content, } \\
\text { including medical writing for } \\
\text { content }\end{array}$ \\
\hline
\end{tabular}

\begin{tabular}{|c|c|c|}
\hline $\begin{array}{l}\text { Susanne } \\
\text { Morlot, MD }\end{array}$ & $\begin{array}{l}\text { Department of Human } \\
\text { Genetics, Hannover } \\
\text { Medical School, Hannover, } \\
\text { Germany }\end{array}$ & $\begin{array}{l}\text { Major role in the acquisition } \\
\text { of data }\end{array}$ \\
\hline
\end{tabular}

Thi Tuyet CHU Sainte Justine Research Analysis or interpretation of Mai Nguyen, Centre, Université de data

PhD Montréal, Montreal, Quebec, Canada

\begin{tabular}{lll}
\hline Rachel Rock, & Biochemical Diseases, BC & $\begin{array}{l}\text { Major role in the acquisition } \\
\text { MD }\end{array}$ \\
Children's Hospital, & Vancouver, British Columbia, \\
& Canada &
\end{tabular}

\begin{tabular}{lll}
\hline Elliot & $\begin{array}{l}\text { Greenwood Genetic Center, } \\
\text { Stolerman, } \\
\text { MD }\end{array}$ & $\begin{array}{l}\text { Major roenwood, in the acquisition } \\
\text { of data }\end{array}$ \\
\hline
\end{tabular}

\begin{tabular}{lll}
\hline Julia Russo, & $\begin{array}{l}\text { Greenwood Genetic Center, } \\
\text { MS }\end{array}$ & $\begin{array}{l}\text { Major role in the acquisition } \\
\text { of data }\end{array}$
\end{tabular}

\begin{tabular}{lll}
\hline $\begin{array}{l}\text { William } \\
\text { Boyce } \\
\text { Burns, MD }\end{array}$ & Greenwood Genetic Center, & Major role in the acquisition \\
of data
\end{tabular}

Burns, MD

\begin{tabular}{lll}
\hline Julie R. & Greenwood Genetic Center, & Major role in the acquisition \\
Jones, PhD & Greenwood, SC, USA & of data
\end{tabular}

\begin{tabular}{lll}
\hline Valentina & Department of Molecular & Drafting/revision of the \\
Serpieri, & Medicine, University of Pavia, & manuscript for content, \\
PhD & Pavia, Italy; Neurogenetics & including medical writing for \\
& Research Center, IRCCS & content \\
& $\begin{array}{l}\text { Mondino Foundation, Pavia, } \\
\text { Italy }\end{array}$ & \\
&
\end{tabular}

\begin{tabular}{lll}
\hline $\begin{array}{l}\text { Hannah } \\
\text { Wallaschek, } \\
\text { MD }\end{array}$ & $\begin{array}{l}\text { Department of Human } \\
\text { Genetics, Hannover } \\
\text { Medical School, Hannover, } \\
\text { Germany }\end{array}$ & $\begin{array}{l}\text { Major role in the acquisition } \\
\text { of data }\end{array}$ \\
\hline $\begin{array}{l}\text { Ginevra } \\
\text { Zanni, MD } \\
\text { PhD }\end{array}$ & $\begin{array}{l}\text { Unit of Neuromuscular and } \\
\text { Neurodegenerative } \\
\text { Disorders, Department } \\
\text { of Neurosciences, } \\
\text { IRCCS, Bambino Gesù } \\
\text { Research Hospital, Rome, } \\
\text { Italy }\end{array}$ & $\begin{array}{l}\text { Major role in the acquisition } \\
\text { of data }\end{array}$ \\
\end{tabular}

\begin{tabular}{lll}
\hline David A. & Department of Genetics, & Drafting/revision of the \\
Dyment, & Children's Hospital of Eastern & manuscript for content, \\
DPhil, MD & $\begin{array}{l}\text { Ontario, Ottawa, Ontario, } \\
\text { Canada; Children's Hospital } \\
\text { of Eastern Ontario Research } \\
\text { Institute, Ottawa, Ontario, } \\
\text { Canada }\end{array}$ & $\begin{array}{l}\text { content, and major role in } \\
\text { the acquisition of data }\end{array}$ \\
&
\end{tabular}

\begin{tabular}{lll}
\hline $\begin{array}{l}\text { Philippe M. } \\
\text { Campeau, }\end{array}$ & $\begin{array}{l}\text { CHU Sainte Justine Research } \\
\text { Centre, Université de }\end{array}$ & $\begin{array}{l}\text { Drafting/revision of the } \\
\text { manuscript for content, } \\
\text { including medical writing for }\end{array}$ \\
MD & $\begin{array}{l}\text { Quebtreal, Montreal, } \\
\text { Genetics Division, }\end{array}$ & $\begin{array}{l}\text { content; major role in the } \\
\text { acquisition of data; study }\end{array}$ \\
& $\begin{array}{l}\text { Department of Pediatrics, } \\
\text { Sainte-Justine University } \\
\text { concept or design; and } \\
\text { Hospital Centre, Montreal, } \\
\text { Quebec, Canada }\end{array}$ & data or interpretation of \\
\end{tabular}

\section{References}

1. Kinoshita T. Biosynthesis and biology of mammalian GPI-anchored proteins. Open Biol. 2020;10(3):190290.

2. Nguyen TTM, Murakami Y, Sheridan E, et al. Mutations in GPAA1, encoding a GPI transamidase complex protein, cause developmental delay, epilepsy, cerebellar atrophy, and osteopenia. Am J Hum Genet. 2017;101(5):856-865.

3. Murakami Y, Kanzawa N, Saito K, et al. Mechanism for release of alkaline phosphatase caused by glycosylphosphatidylinositol deficiency in patients with hyperphosphatasia mental retardation syndrome. J Biol Chem. 2012;287(9):6318-6325.

4. Um JW, Ko J. Neural glycosylphosphatidylinositol-anchored proteins in synaptic specification. Trends Cel Biol. 2017;27(12):931-945.

5. Almeida AM, Murakami Y, Layton DM, et al. Hypomorphic promoter mutation in PIGM causes inherited glycosylphosphatidylinositol deficiency. Nat Med. 2006; 12(7):846-851.

6. Ohba C, Okamoto N, Murakami Y, et al. PIGN mutations cause congenital anomalies, developmental delay, hypotonia, epilepsy, and progressive cerebellar atrophy. Neurogenetics. 2014;15(2):85-92.

7. Kvarnung M, Nilsson D, Lindstrand A, et al. A novel intellectual disability syndrome caused by GPI anchor deficiency due to homozygous mutations in PIGT. J Med Genet. 2013;50(8):521-528.

8. Ilkovski B, Pagnamenta AT, O'Grady GL, et al. Mutations in PIGY: expanding the phenotype of inherited glycosylphosphatidylinositol deficiencies. Hum Mol Genet. 2015;24(21):6146-6159.

9. Nguyen TTM, Murakami Y, Mobilio S, et al. Bi-allelic variants in the GPI transamidase subunit PIGK cause a neurodevelopmental syndrome with hypotonia, cerebellar atrophy, and epilepsy. Am J Hum Genet. 2020;106(4):484-495.

10. Hamburger D, Egerton M, Riezman H. Yeast Gaalp is required for attachment of a completed GPI anchor onto proteins. J Cel Biol. 1995;129(3):629-639.

11. Wu G, Guo Z, Chatterjee A, et al. Overexpression of glycosylphosphatidylinositol (GPI) transamidase subunits phosphatidylinositol glycan class T and/or GPI anchor attachment 1 induces tumorigenesis and contributes to invasion in human breast cancer. Cancer Res. 2006;66(20):9829-9836.

12. Gagnier JJ, Kienle G, Altman DG, Moher D, Sox H, Riley D. The CARE guidelines: consensus-based clinical case report guideline development. J Clin Epidemiol. 2014; 67(1):46-51.

13. Pu JJ, Brodsky RA. Paroxysmal nocturnal hemoglobinuria from bench to bedside. Clin Transl Sci. 2011;4(3):219-224.

14. Bellai-Dussault K, Nguyen TTM, Baratang NV, Jimenez-Cruz DA, Campeau PM. Clinical variability in inherited glycosylphosphatidylinositol deficiency disorders. Clin Genet. 2019;95(1):112-121.

15. Vetro A, Pisano T, Chiaro S, et al. Early infantile epileptic-dyskinetic encephalopathy due to biallelic PIGP mutations. Neurol Genet. 2020;6(1):e387.

16. Knaus A, Pantel JT, Pendziwiat M, et al. Characterization of glycosylphosphatidylinositol biosynthesis defects by clinical features, flow cytometry, and automated image analysis. Genome Med. 2018;10(1):3-13.

17. Orlean P, Menon AK. GPI anchoring of protein in yeast and mammalian cells, or: how we learned to stop worrying and love glycophospholipids. J Lipid Res. 2007;48(5): 993-1011.

18. Diemar SS, Sejling AS, Eiken P, Andersen NB, Jørgensen NR. An explorative literature review of the multifactorial causes of osteoporosis in epilepsy. Epilepsy Behav. 2019; 100(Pt A): 106511.

19. Nakashima M, Kashii H, Murakami Y, et al. Novel compound heterozygous PIGT mutations caused multiple congenital anomalies-hypotonia-seizures syndrome 3. Neurogenetics. 2014;15(3):193-200.

20. Kinoshita T. Biosynthesis and deficiencies of glycosylphosphatidylinositol. Proc Jpn Acad Ser B Phys Biol Sci. 2014;90(4):130-143.

21. Nguyen TTM, Murakami Y, Wigby KM, et al. Mutations in PIGS, encoding a GPI transamidase, cause a neurological syndrome ranging from fetal akinesia to epileptic encephalopathy. Am J Hum Genet. 2018;103(4):602-611.

22. Knaus A, Kortüm F, Kleefstra T, et al. Mutations in PIGU impair the function of the GPI transamidase complex, causing severe intellectual disability, epilepsy, and brain anomalies. Am J Hum Genet. 2019;105(2):395-402.

23. Pagnamenta AT, Murakami Y, Taylor JM, et al. Analysis of exome data for 4293 trios suggests GPI-anchor biogenesis defects are a rare cause of developmental disorders. Eur J Hum Genet. 2017;25(6):669-679.

24. van der Crabben SN, Harakalova M, Brilstra EH, et al. Expanding the spectrum of phenotypes associated with germline PIGA mutations: a child with developmental delay, accelerated linear growth, facial dysmorphisms, elevated alkaline phosphatase, and progressive CNS abnormalities. Am J Med Genet A. 2014;164(1):29-35.

25. Zhao JJ, Halvardson J, Knaus A, et al. Reduced cell surface levels of GPI-linked markers in a new case with PIGG loss of function. Hum Mutat. 2017;38(10): 1394-1401.

26. Fujiwara I, Murakami Y, Niihori T, et al. Mutations in PIGL in a patient with Mabry syndrome. Am J Med Genet A. 2015;167A(4):777-785.

27. Kettwig M, Elpeleg O, Wegener E, et al. Compound heterozygous variants in PGAP1 causing severe psychomotor retardation, brain atrophy, recurrent apneas and delayed myelination: a case report and literature review. BMC Neurol. 2016;16(1):74-77.

28. Makrythanasis P, Kato M, Zaki MS, et al. Pathogenic variants in PIGG cause intellectual disability with seizures and hypotonia. Am J Hum Genet. 2016;98(4):615-626.

29. Li Y, Yang L, Yang J, et al. A novel variant in GPAA1, encoding a GPI transamidase complex protein, causes inherited vascular anomalies with various phenotypes. Hum Genet. 2020;1390(12):1499-1511. 
30. Almeida AM, Murakami Y, Baker A, et al. Targeted therapy for inherited GPI deficiency. N Engl J Med. 2007;356(16):1641-1647.

31. Almeida A, Layton M, Karadimitris A. Inherited glycosylphosphatidyl inositol deficiency: a treatable CDG. Biochim Biophys Acta. 2009;1792(9): 874-880.

32. Joshi C, Kolbe DL, Mansilla MA, Mason S, Smith RJH, Campbell CA. Ketogenic diet-a novel treatment for early epileptic encephalopathy due to PIGA deficiency. Brain Dev. 2016;38(9):848-851.
33. Thompson MD, Killoran A, Percy ME, Nezarati M, Cole DEC, Hwang PA. Hyperphosphatasia with neurologic deficit: a pyridoxine-responsive seizure disorder? Pediatr Neurol. 2006;34(4):303-307.

34. Kuki I, Takahashi Y, Okazaki S, et al. Vitamin B6-responsive epilepsy due to inherited GPI deficiency. Neurology. 2013;81(16):1467-1469.

35. Su CT. Structural modelling of the lumenal domain of human GPAA1, the metallopeptide synthetase subunit of the transamidase complex, reveals zinc-binding mode and two flaps surrounding the active site, preprint. 


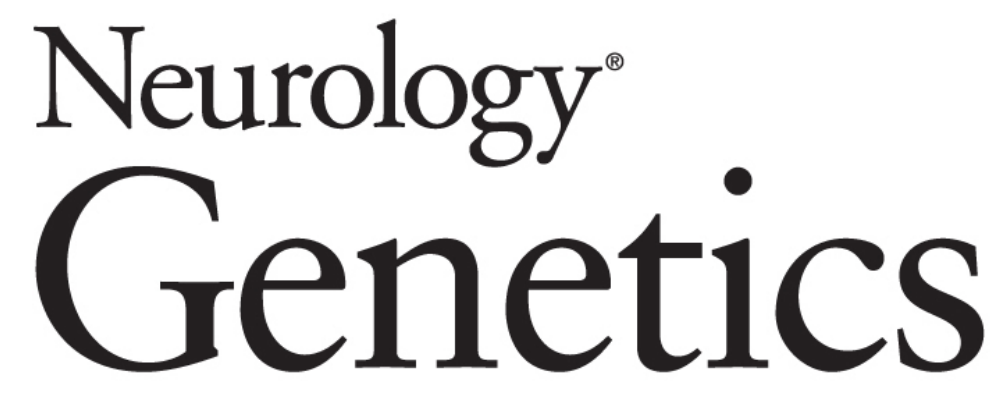

\section{Expanding the Phenotypic Spectrum of GPI Anchoring Deficiency Due to Biallelic Variants in GPAA1}

Alison M.R. Castle, Smrithi Salian, Haim Bassan, et al.

Neurol Genet 2021;7;

DOI 10.1212/NXG.0000000000000631

This information is current as of October 21, 2021

\section{Updated Information \&} Services

References

Subspecialty Collections

Permissions \& Licensing

Reprints including high resolution figures, can be found at: http://ng.neurology.org/content/7/6/e631.full.html

This article cites 34 articles, 6 of which you can access for free at: http://ng.neurology.org/content/7/6/e631.full.html\#\#ref-list-1

This article, along with others on similar topics, appears in the following collection(s):

\section{All Genetics}

http://ng.neurology.org//cgi/collection/all_genetics

Developmental disorders

http://ng.neurology.org//cgi/collection/developmental_disorders

Information about reproducing this article in parts (figures,tables) or in its entirety can be found online at:

http://ng.neurology.org/misc/about.xhtml\#permissions

Information about ordering reprints can be found online:

http://ng.neurology.org/misc/addir.xhtml\#reprintsus

Neurol Genet is an official journal of the American Academy of Neurology. Published since April 2015, it is an open-access, online-only, continuous publication journal. Copyright Copyright $\odot 2021$ The Author(s). Published by Wolters Kluwer Health, Inc. on behalf of the American Academy of Neurology.. All rights reserved. Online ISSN: 2376-7839.

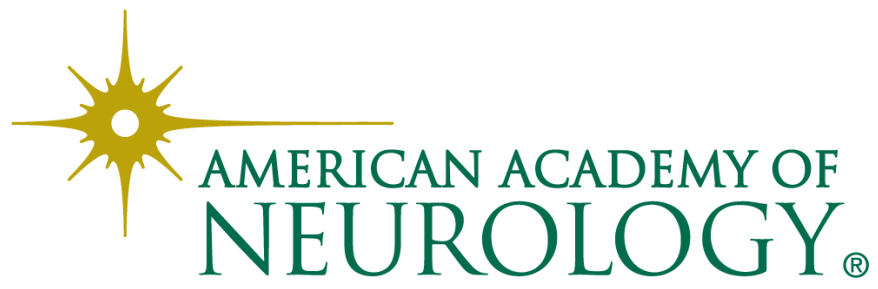

